\title{
False spider mites (Acari: Tenuipalpidae) as pests on orchids (Phalaenopsis hybrids) in Poland
}

\author{
GABRIEL ŁABANOWSKI and GRAŻYNA SOIKA \\ Institute of Horticulture, Pomologiczna 18, 96-100 Skierniewice, Poland \\ Corresponding author: Gabriel Łabanowski, gabriel.labanowski@inhort.pl
}

(Received on 13 May 2010; Accepted on 23 May 2011)

\begin{abstract}
So far, no false spider mites have been reported from orchids in Poland. This paper provides information about Tenuipalpus pacificus Baker, which was recorded for the first time in Poland, on Phalaenopsis hybrids imported from China. Diagnostic characters are also given for Brevipalpus phoenicis (Geijskes), which was up to this time not found on orchids in Poland. It was earlier found on orchids only in Hawaii. The types of injuries caused by false spider mites and results of chemical control of $T$. pacificus with various acaricides are given. The best results were observed after repeated treatment with Ortus 05 SC (fenpyroximate).
\end{abstract}

Keywords: Tenuipalpus pacificus, Brevipalpus phoenicis, Phalaenopsis hybrids, chemical control

\section{INTRODUCTION}

The family Tenuipalpidae is worldwide in distribution and consists of 891 species belonging to 34 genera (Mesa et al. 2009). However, in Poland until recently only 5 species of this family were found:

1. Cenopalpus lineola (Canestrini \& Fanzago) - on Pinus sylvestris (BoczeK \& KROPCZYŃSKA 1964);

2. Cenopalpus pulcher (Canestrini \& Fanzago) - on Malus sp. (BoczeK \& KROPCZYŃSKA 1964);

3. Brevipalpus phoenicis (Geijskes) - on Phoenix dactylifera, Marantha leuconeura, and Cyclamen persicum (LABANOWSKI 1995);

4. Brevipalpus obovatus Donnadieu - on Rhododendron simsii, Citrus, and Cissus spp. (Łabanowski 1995); and

5. Pentamerismus taxi (Haller) - on Taxus baccata (ŁaBAnowski \& SoIKA 2006). 
Worldwide, only 6 tenuipalpid species have been reported on orchids so far. Half of the species belong to the genus Brevipalpus Donnadieu: B. phoenicis (Geijskes), $B$. californicus (Banks), and B. oncidii Baker. The other 3 species represent the genus Tenuipalpus Donnadieu: T. pacificus (Baker), T. orchidarum Parfitt, and T. orchidofilo Moraes \& Freire. In the present study we focus on B. phoenicis and T. pacificus, because they have been recently found for first time on orchids (Phalaenopsis hybrids) in Poland, but first we will briefly describe the other species.

Mites belonging to the genus Brevipalpus feeding on orchids include the oncidium mite Brevipalpus oncidii Baker (favourite hosts: Odontoglossum and Oncidium) and the omnivorous mite B. californicus (Banks) - also known as B. australis (Trucker) - with a wide host range: citrus, rubber plants, tea, and other tropical plants. Among orchids, the latter species feeds on Odontoglossum, Dendrobium, Lycaste, Stanhopen, Trichophila, Peristeria, Epidendrum, Gongor, Brassia, Catasetum, Houlletia, Acineta, Anguloa, and Bletia spp. (Pritchard 1951; Denmark 2009). Species such as B. californicus (Banks), B. obovatus Donn. and B. phoenicis (Geijskes) have been incriminated as vectors of at least one unassigned rhabdovirus (CHILDERS \& DERRICK 2003).

Brevipalpus phoenicis, named the red and black flat mite, was earlier recorded in Poland on various plants. For the first time, in 1961, it was collected from Phoenix dactylifera (BOCZEK \& KROPCZYŃSKA 1964), and in 1986-1991 severe damages were observed on leaves of this plant, as silvering and brown spots near the main veins. This mite species also caused damages on Marantha leuconeura and Cyclamen persicum, as ridges around leaf blades (ŁABANOWSKI 1995). This species was described from specimens collected from Phoenix sp. in a greenhouse in the Netherlands, but it is widely distributed all over the word (Hatzinikolis 1986). Host plants of B. phoenicis belong to 64 families, 118 genera, and 486 species, but it is known mostly as a pest of citrus and tea (CHILDERs et al. 2003). B. phoenicis has been reported on orchids only from Hawaii so far (Kessing \& MAU 1992). Currently there are 4 viruses known to be associated with the Brevipalpus-phoenicis complex, and they include the orchid-fleck-virus (OFV), which appeared on Phalaenopsis as chlorotic flecks (AnONYMOUS 2009).

Mites belonging to the genus Tenuipalpus feeding on orchids are: T. pacificus (Baker, 1935), T. orchidarum (Parfitt, 1859), and T. orchidofilo Moraes \& Freire, 2001. The first species will be described in detail below. T. orchidarum was initially described by Parfitt in 1859 as Acarus orchidarum and in 1875 by Donnadieu as Brevipalpus perger. It also feeds on orchids: Phalaenopsis and Cypripedium (Dosse 1954). By contrast, T. orchidofilo Moraes \& Freire, 2001 was described only 10 years ago, from Brazil, on the basis of the mobile juveniles and adult stages collected on the orchid Arundina graminifolia.

Tenuipalpus pacificus was described by Baker in the USA from Phalaenopsis stuartiana in 1943, but it has been introduced on orchids from the tropic areas also to other regions and is known in Australia, England, Germany, the Netherlands, Java, Panama, Philippines, Siam, and the United States (DENMARK 1968). Host plants for this mite are orchids: Aerides, Cattleya, Cypripedium, Dendrobium, Grammatophyl- 
lum, Oncidium, Phalaenopsis, Saccolabium spp., but also ferns from the family Polypodiaceae: Davallia fejeensis and Platycerium spp. (DenMARK 1968).

In commercial greenhouses the damage of Phalaenopsis plants caused by $T$. pacificus was clearly visible on the upper and lower leaf surfaces, and the number of mites was relatively high already, so treatment with acaricides was necessary. Thus in this study we present results of treatment of the infested orchids with several acaricides. Additionally we describe the morphology of B. phoenicis and T. pacificus on Phalaenopsis hybrids, as these are the first observations of false spider mites on orchids in Poland.

\section{MATERIAL AND METHODS}

Observations on the occurrence of alien invasive mites and insects on ornamental plants, including orchids, were carried out in 1995-2009. Samples of the damaged plants were collected in commercial glasshouses, and in the laboratory the samples were examined for the presence of tenuipalpid mites. Individuals were mounted on glass slides in Heinze medium and were dried for 2 weeks at $60{ }^{\circ} \mathrm{C}$. Their morphology was studied under a phase-contrast microscope, and species of tenuipalpids were identified according to DenMark (1968) and Zhang's (2003) descriptions.

In 2008, in a glasshouse with Phalaenopsis 'Taisuco Beauty' (formerly known as $\times$ Doritaenopsis 'Taisuco Beauty') plants heavily infested by T. pacificus, an experiment was conducted with several new acaricides, namely: Borneo $110 \mathrm{SC}$ (etoxazole), Envidor $240 \mathrm{SC}$ (spirodiclofen), Floramite 240 SC (bifenazat), and Ortus 05 $\mathrm{SC}$ (fenpyroximate). The results were compared with the reference product Talstar 100 EC (bifenthrin). The trial was conducted in a randomized design with 3 replicates, each consisting of 5 plants. The treatments were applied onto plants with a handle sprayer 'Venus', using $1000 \mathrm{~L}$ of the solution per ha. Motile forms and eggs of T. pacificus collected on 2" leaves from 5 plants, using a mite-brushing machine (HeNDERSON \& McBurnie 1943) were counted at the following observation periods: before treatment (PRE-T), 7 days after the first treatment $(\mathrm{T} 1+7), 7$ days after the second treatment $(\mathrm{T} 2+7)$, as well as 14 days $(\mathrm{T} 2+14)$ and 21 days $(\mathrm{T} 2+21)$ after the second treatment. The results were subjected to analysis of variance (ANOVA) after transformation of the data according to the function $y=\log (x+1)$. The significance of differences between means was evaluated using the Duncan $t$-test at $P=0.05$. Data are also presented as efficacy (\%), calculated according to the Henderson-Tilton formula.

\section{RESULTS AND DISCUSSION}

During the observation period in the collected samples of orchids, 2 species of Tenuipalpidae were found: Brevipalpus phoenicis on a Phalaenopsis hybrid (in Konstantynów Łódzki on 30 Aug 2002) and Tenuipalpus pacificus on various Phalaenopsis hybrids, namely Sogo cultivars 'Yokidian', 'Taisuco Beauty', 'Alice Girl' and 'Baldan's Kaleidoskop' imported from China (in Skierniewice on 26 and 31 Oct 2007; 8 Feb 2008; 28 Mar 2008, 26 Sep 2009; 16 Dec 2009, all stages). 

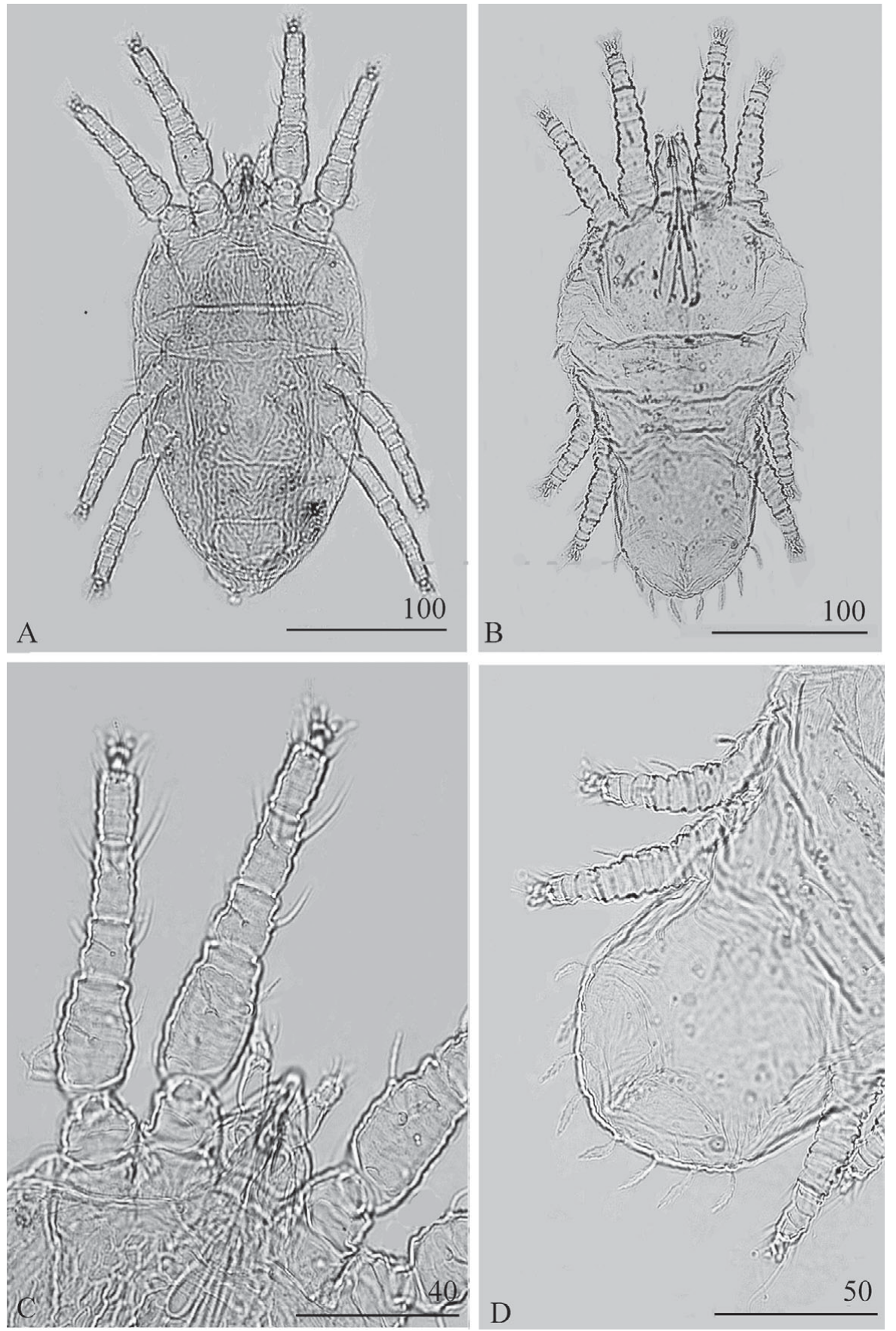

Fig. 1. Brevipalpus phoenicis: A - dorsal view of female, B - ventral view of male, C - legs, $\mathrm{D}$ - hysterosoma. Scale bar $(\mu \mathrm{m})$ 
On the observed plants, B. phoenicis mites feeding on the upper leaf surface and feeding injury is firstly noted as stippling (silvering), which eventually becomes rusty and brown. Females are elliptical, flat, reddish orange, with a black H-shaped mark. Males are reddish and more wedge-shaped than females, without black markings. Larvae are 6-legged and bright orange-red when newly emerged, and opaque orange when fully grown, with a pair of distinct lateral darkish areas on the idiosomal dorsum. The protonymph is similar to the larva, but it differs by marginal seta IV of the hysterosoma, which is lanceolate and serrate. The deutonymph is similar in appearance to the protonymphs except for having an extra pair of legs and 2 additional setae. The eggs are elliptical in shape, with a stipe, reddish orange soon after laid, but later they become darker. More detailed descriptions are given by НАRАмото (1969), LAL (1978), and ZHANG (2003). Some diagnostic characters of collected females and males in microscopic slides are presented in Fig. 1 and they are in agreement with the description given by RAHMANI et al. (2008).

Observations of damages caused by T. pacificus indicate that this mite is one of the most destructive pests, which can be found on orchids under greenhouse conditions. The mite feeds on both sides of the leaf, but prefers the lower surface. It pierces the epidermis and removes the chlorophyll, causing the plant tissue to become silvery in appearance. Damaged plants have dark spots on the upper leaf surface. Females collected from Phalaenopsis are dark reddish, with a dorsal ornamentation consisting of a few longitudinal striae. In microscopic slides the main characters of collected females and males are presented in Fig. 2. The body is abruptly narrowed behind legs IV and bearing a pair of long whip-like setae near the posterior end. The palp is 3-segmented, and its third, terminal segment is small, with a short straight seta and a longer, slightly curved seta. The hysterosoma has 4 pairs of nonflagellate setae and a pair of flagellate setae caudally. The male has the same general appearance as the female, except the smaller and narrower body. All this is in agreement with the description given by DENMARK (1968).

The best results for the control of $T$. pacificus motile forms (their number reduced by over $85 \%$ at 14 and 21 days after the second application) were obtained with Ortus $05 \mathrm{SC}$ (fenpyroximate) at a concentration of $0.1 \%$. A lower efficacy (less than $75 \%$ ) was recorded for Floramite $240 \mathrm{SC}$ (bifenazat) at $0.05 \%$ and Borneo (etoxazole) at $0.05 \%$. The long-term effect ( 21 days after the second treatment) against motile forms was also provided by Envidor $240 \mathrm{SC}$ (spirodiclofen) at a concentration of $0.05 \%$. All new products showed better results for the control than the reference product - Talstar 100 EC (Table 1). According to ReIs et al. (2005), this product at a dose of $300 \mathrm{ml} / \mathrm{ha}$ gave the best results in the control of B. phoenicis on coffee plants, as on 15 days after treatment its efficacy against motile forms was equal to $100 \%$ and against eggs, to $98.4 \%$. A relatively low efficacy of all tested products was found for eggs (Table 2). In Germany, abamectin, spirodiclofen, and tebufenpyrad are recommended for the control of this mite species on orchids, in intervals of 2-3 weeks, with changing agents, until the new leaves are visibly free from infestation (ANONYMOUS 2008). 


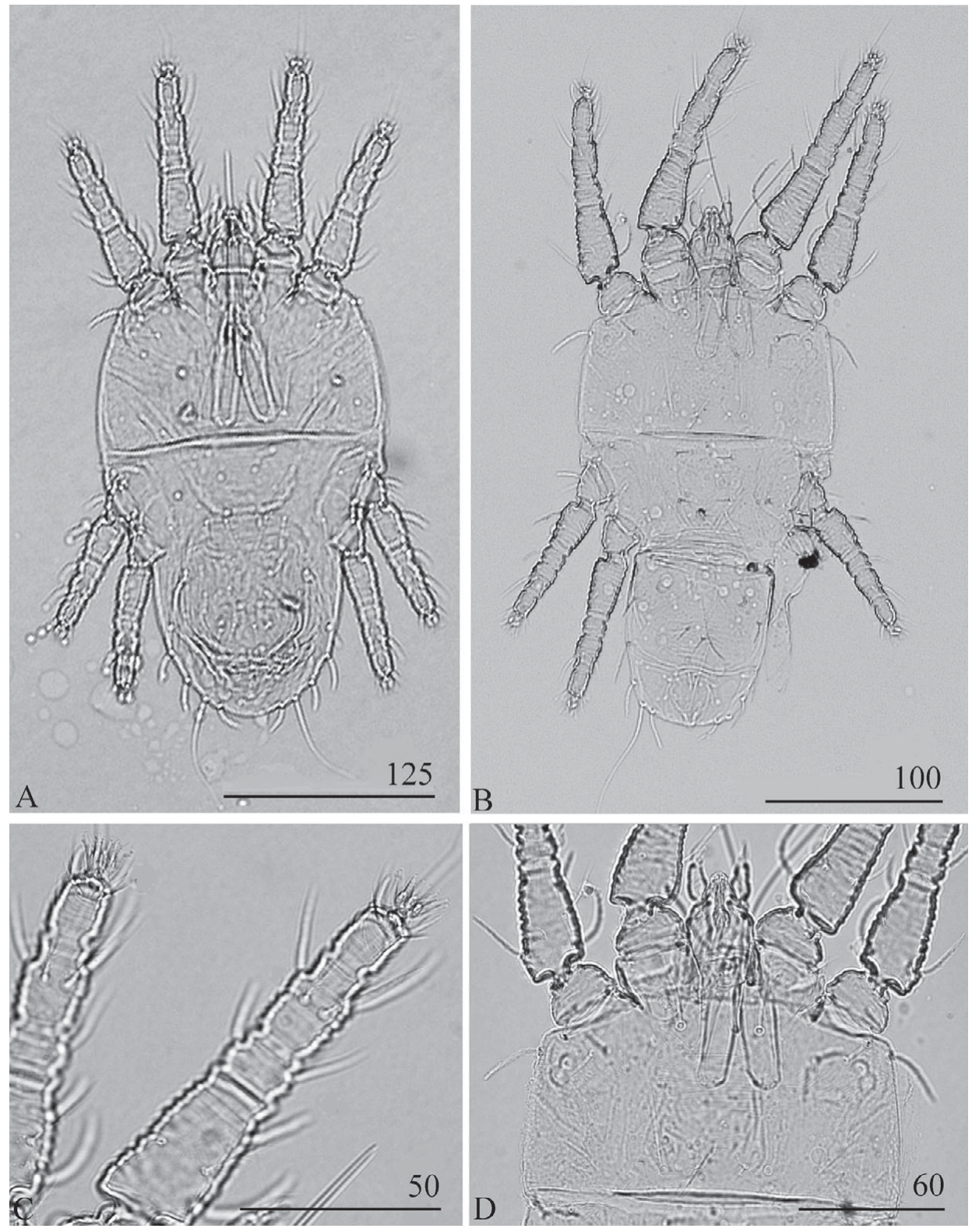

Fig. 2. Tenuipalpus pacificus: A - ventral view of female, B - ventral view of male, C - legs. $\mathrm{D}$ - propodosoma, Scale bar $(\mu \mathrm{m})$ 
Table 1. Efficacy of acaricides against motile forms of Tenuipalpus pacificus on Phalaenopsis 'Taisuco Beauty'

\begin{tabular}{|c|c|c|c|c|c|}
\hline \multirow{2}{*}{$\begin{array}{l}\text { Acaricide type and } \\
\text { concentration }(\%)\end{array}$} & \multicolumn{5}{|c|}{ Period of observation in days after treatments ( $\mathrm{T} 1$ and $\mathrm{T} 2$ ) } \\
\hline & PRE-T & $\mathrm{T} 1+7$ & $\mathrm{~T} 2+7$ & $\mathrm{~T} 2+14$ & $\mathrm{~T} 2+21$ \\
\hline \multicolumn{6}{|c|}{ Mean no. of motile forms per 2.5 leaves } \\
\hline Floramite $240 \mathrm{SC}-0.05$ & $1097.8 \mathrm{a}$ & $267.8 \mathrm{ab}$ & $227.4 \mathrm{a}$ & $236.5 \mathrm{~b}$ & $206.5 \mathrm{~b}$ \\
\hline Talstar $100 \mathrm{EC}-0.05$ & $941.1 \mathrm{a}$ & $589.0 \mathrm{bc}$ & $372.5 \mathrm{ab}$ & $393.3 \mathrm{bc}$ & $285.4 \mathrm{bc}$ \\
\hline Borneo $110 \mathrm{SC}-0.05$ & $1204.4 \mathrm{a}$ & $617.2 \mathrm{bc}$ & $215.7 \mathrm{a}$ & $270.6 \mathrm{~b}$ & $220.3 \mathrm{~b}$ \\
\hline Ortus $05 \mathrm{SC}-0.1$ & $701.8 \mathrm{a}$ & $250.4 \mathrm{a}$ & $247.0 \mathrm{a}$ & $82.9 \mathrm{a}$ & $43.5 \mathrm{a}$ \\
\hline Envidor $240 \mathrm{SC}-0.05$ & $656.0 \mathrm{a}$ & $559.5 \mathrm{bc}$ & $380.2 \mathrm{ab}$ & $232.4 \mathrm{~b}$ & $87.7 \mathrm{a}$ \\
\hline Control (no treatment) & $818.1 \mathrm{a}$ & $799.0 \mathrm{c}$ & $661.6 \mathrm{~b}$ & $659.9 \mathrm{c}$ & $527.1 \mathrm{c}$ \\
\hline \multicolumn{6}{|c|}{ Efficacy (\%) according to Henderson-Tilton formula } \\
\hline Floramite $240 \mathrm{SC}-0.05$ & - & 75.0 & 74.4 & 73.3 & 70.8 \\
\hline Talstar $100 \mathrm{EC}-0.05$ & - & 35.9 & 51.1 & 48.2 & 52.9 \\
\hline Borneo $110 \mathrm{SC}-0.05$ & - & 47.5 & 77.9 & 72.1 & 71.6 \\
\hline Ortus $05 \mathrm{SC}-0.1$ & - & 63.5 & 56.9 & 85.4 & 90.4 \\
\hline Envidor $240 \mathrm{SC}-0.05$ & - & 12.7 & 28.3 & 56.1 & 79.3 \\
\hline
\end{tabular}

Location - greenhouse in Skierniewice, date of spray treatments: 23 and 30 April 2008.

Means followed by the same letter within columns do not differ significantly (Duncan multiple range test, $P=0.05$ ).

Table 2. Efficacy of acaricides against eggs of Tenuipalpus pacificus on Phalaenopsis 'Taisuco Beauty'

\begin{tabular}{|c|c|c|c|c|c|}
\hline \multirow{2}{*}{$\begin{array}{l}\text { Acaricide type and } \\
\text { concentration }(\%)\end{array}$} & \multicolumn{5}{|c|}{ Period of observation in days after treatments ( $\mathrm{T} 1$ and $\mathrm{T} 2$ ) } \\
\hline & PRE-T & $\mathrm{T} 1+7$ & $\mathrm{~T} 2+7$ & $\mathrm{~T} 2+14$ & $\mathrm{~T} 2+21$ \\
\hline \multicolumn{6}{|c|}{ Mean no. of eggs per 2.5 leaves } \\
\hline Floramite $240 \mathrm{SC}-0.05$ & $1620.2 \mathrm{a}$ & $941.9 \mathrm{a}$ & $1018.1 \mathrm{a}$ & $1091.7 \mathrm{a}$ & $853.4 \mathrm{bc}$ \\
\hline Talstar $100 \mathrm{EC}-0.05$ & $1305.3 \mathrm{a}$ & $1041.7 \mathrm{a}$ & $1612.2 \mathrm{ab}$ & $1750.1 \mathrm{a}$ & $1580.9 \mathrm{~cd}$ \\
\hline Borneo $110 \mathrm{SC}-0.05$ & $1286.5 \mathrm{a}$ & $1213.7 \mathrm{a}$ & $1395.9 \mathrm{ab}$ & $1628.9 \mathrm{a}$ & $1773.1 \mathrm{~cd}$ \\
\hline Ortus $05 \mathrm{SC}-0.1$ & $1087.1 \mathrm{a}$ & $694.8 \mathrm{a}$ & $899.6 \mathrm{a}$ & $863.3 \mathrm{a}$ & $433.6 \mathrm{a}$ \\
\hline Envidor $240 \mathrm{SC}-0.05$ & $1147.3 \mathrm{a}$ & $1156.2 \mathrm{a}$ & $1146.8 \mathrm{ab}$ & $1122.6 \mathrm{a}$ & $585.8 \mathrm{ab}$ \\
\hline Control (no treatment) & $1100.2 \mathrm{a}$ & 1310.7 a & $2143.8 \mathrm{~b}$ & $1785.3 \mathrm{a}$ & $1844.5 \mathrm{~d}$ \\
\hline \multicolumn{6}{|c|}{ Efficacy (\%) according to Henderson-Tilton formula } \\
\hline Floramite $240 \mathrm{SC}-0.05$ & - & 51.2 & 67.8 & 58.5 & 68.6 \\
\hline Talstar 100 EC -0.05 & - & 33.0 & 36.6 & 17.4 & 27.8 \\
\hline Borneo $110 \mathrm{SC}-0.05$ & - & 20.8 & 44.3 & 22.0 & 17.8 \\
\hline Ortus $05 \mathrm{SC}-0.1$ & - & 46.4 & 57.5 & 51.1 & 76.2 \\
\hline Envidor $240 \mathrm{SC}-0.05$ & - & 15.4 & 48.7 & 39.7 & 69.5 \\
\hline
\end{tabular}

Explanations: see Table 1. 


\section{CONCLUSIONS}

1. Phalaenopsis hybrid is the first reported orchid host for Brevipalpus phoenicis (Geijskes) in Poland. It was earlier recorded on orchids only in Hawaii (Kessing \& MAU 1992).

2. Tenuipalpus pacificus (Baker) was recorded for the first time in Poland. It was found on Phalaenopsis hybrids 'Yokidian', 'Taisuco Beauty', 'Alice Girl', 'Baldan's Kaleidoskop' imported from China, but it was eradicated from the commercial glasshouses in Skierniewice, where its was found.

3. The most effective control against motile forms of $T$. pacificus was obtained with Ortus 05 SC (fenpyroximate) at a concentration of $0.1 \%$, applied as 2 spray-treatments with a 7-day interval. A relatively low efficacy of all the tested products was observed for eggs.

\section{REFERENCES}

Anonymous 2008. Orchid mites. I.+A. Hark Orchideen GmbH \&Co. KG, Lippstadt, Germany. http://www.hark-orchideen.de

Anonymous 2009. Flat mites and orchid fleck virus (OFV). http://www.florento.nl/html/nl_info. html

BoczeK J., KropczyŃska D. 1964. Badania nad roztoczami (Acarina) występującymi na roślinach w Polsce [Investigations of mites (Acarina) occurring on plants in Poland]. I. Frag. Faun. 11: 161-188 (in Polish).

Childers C. C., Derrick K. 2003. Brevipalpus mites as vectors of unassigned rhabdoviruses in various crops. Exp. Appl. Acarol. 30: 1-3.

Childers C. C., Rodrigues J. C. V., Welbourn W. C. 2003. Host plants of Brevipalpus californicus, B. obovatus, and B. phoenicis (Acari: Tenuipalpidae) and their potential involvement in the spread of viral diseases vectors by these mites. Exp. Appl. Acarol. 30: 29-105.

Denmark H. A. 1968. Phalaenopsis mite, Tenuipalpus pacificus Baker. Entomol. Circ. 74: 1.

Denmark H. A. 2009. A false spider mite, Brevipalpus californicus (Banks) (Arachnida: Acari: Tenuipalpidae). EENY-384: 1-4. http://www.edis.ifas.ufl.edu/pdffiles/IN/IN69000.pdf

Dosse G. 1954. Tenuipalpus orchidarum Parfitt nun auch in deutschen Gewächshäusern. Z. Angew. Entomol. 36: 304-315.

HaRAmoto F. H. 1969. Biology and control of Brevipalpus phoenicis (Geijskes) (Acarina: Tenuipalpidae). Hawaii Agric. Exp. Sta. Tech. Bull. 68: 1-63.

HatziniKolis E. N. 1986. The genus Brevipalpus in Greece (Acari: Tenuipalpidae). Entomol. Hell. 4: $37-48$.

Henderson C. F., McBurnie H. V. 1943. Sampling technique for determining populations of the citrus red mite and its predators. USDA Circular 671: 1-11.

Kessing J. L. M., MAU R. F. L. 1992. Brevipalpus phoenicis (Geijskes) - red and black flat mite. http://www.extento.hawaii.edu/kbase/Crop/Type/b phoeni.htm

LAL L. 1978. Biology of Brevipalpus phoenicis (Geijskes) (Tenuipalpidae: Acarina). Acarologia 20: $97-101$.

ŁaBAnowski G. S. 1995. The false spider mites (Tenuipalpidae) of genus Brevipalpus as pests of potted plants. In: The Acari - physiological and ecological aspects of Acari-host relationships (KropczyŃsKa D., Boczek J., TomczyK A., Eds.), pp. 549-550, Oficyna Dabor, Warszawa. 
Łabanowski G., Solka G. 2006. Pentamerismus taxi (Haller, 1877) (Acari: Tenuipalpidae) as a new record for the Polish fauna. In: Postępy polskiej akarologii [Advances in Polish acarology] (Ignatowicz S., Ed.), pp. 199-202, SGGW, Warszawa.

Mesa N. C., Ochoa R., Welbourn W. C., Evans G. A., Moraes de G. J. 2009. A catalog of the Tenuipalpidae (Acari) of the world with a key to genera. Zootaxa 2098: 1-185.

Pritchard A. E. 1951. Control of orchid mites - false spider mites and spider mite must be distinguished for proper control purposes. Calif. Agric. 8: 11.

Reis P. R., Neto M. P., Franco R. A. 2005. Controle de Brevipalpus phoenicis (Geijskes, 1939) e Oligonychus ilicis (McGregor, 1917) (Acari: Tenuipalpidae, Tetranychidae) em caffeiro e o impacto sobre ácaros benéficos. II - spirodiclofen e azocyclotin. Cięne. Agrotec. 29: 528-537.

Rahmani H., Kamali K., Fathipour Y. 2008. A new record for Iranian false spiker mites with key to the known species of Tenuipalpidae (Acari: Prostigmata) in Iran. Turk. J. Ent. 32: 163-175.

Zhang Z.-Q. 2003. False spider mites. Mites of greenhouses. Identification, biology and control 5: 87-98. 